Cox, J.E. 1978. Soils and agriculture of part Paparua County, Canterbury, New Zealand. New Zealand Soil Bureau Bulletin 34: 128 pp.

Dear, B.S.; Sandral, G.A. 1997. Subterranean clover in NSW - identification and use. Agfact P2.5.16 Dubbo, New South Wales: NSW Agriculture.

Dear, B.S.; Sandral, G.A. 1999. The phytotoxicity of the herbicides bromoxynil, pyridate, imazethapyr and a bromoxynil + diflufenican mixture on subterranean clover and lucerne seedlings. Australian Journal of Experimental Agriculture 39: 839-847.

Dear, B.S.; Sandral, G.A.; Coombes, N.E. 1995 Differential tolerance of Trifolium subterraneum L. (subterranean clover) cultivars to broadlea herbicides 1. Herbage yield. Australian Journal of Experimental Agriculture 35: 467-474.

Dear, B.S.; Sandral, G.A.; Wilson, B.C.D. 2006. Tolerance of perennial pasture grass seedlings to pre-and post-emergent grass herbicides. Animal Production Science 46: 637-644.

Dodd, M.B.; Sheath, G.W.; Tarbotton, I.S. 1995. Development of subterranean clover (Trifolium subterraneum L.) genotypes for New Zealand pastures 3. Whatawhata production evaluation. New Zealand Journal of Agricultural Research 38: 57-63. Fedtke, C.; Duke, S.O. 2004. Herbicides. pp. 247-330. In: Plant toxicology. Eds. Hock, B.; Elstner, E. F. $4^{\text {th }}$ Ed., New York: CRC Press.

Hewitt, A.E. 2010. New Zealand Soil Classification. $4^{\text {th }}$ Ed. New Zealand: Manaaki Whenua-Landcare Research New Zealand Limited.

Lucas, R.J.; Mills, A.; Wright, S.; Black, A.D.; Moot, D.J. 2015. Selection of sub clover cultivars for New Zealand dryland pastures. Proceedings of the New Zealand Grasslands Association 77: 203-210.

Mills, A.; Lucas, R.J.; Moot, D.J. 2014. 'MaxClover' grazing experiment: I. Annual yields, botanical composition and growth rates of six dryland pastures over nine years. Grass and Forage Science 70: 557. 570

Monks, D.; Moot, D.J.; Belgrave, B.; Rolston, M.P.; Caradus, J.R. 2016. Availability of seed for hill country adapted forage legumes. Grassland Research and Practice Series 16: 257-265.

Montgomery, D.C. 2013. Nested and split-plot designs. pp. 604-641. In: Design and analysis of experiments. $8^{\text {th }}$ Ed. United States: John Wiley \& Sons, Inc.

Moot, D.; Scott, W.; Roy, A.; Nicholls, A. 2000. Base temperature and thermal time requirements for germination and emergence of temperate pasture species. New Zealand Journal of Agricultural Research, 43: 15-25.

Moot, D.J.; Black, A.D.; Scott, W.R.; Richardon, J. 2003. Leaf development and dry matter production of subterranean clover cultivars in relation to autumn sward management. Grassland Research and Practice Series 11: 193-200.

OEPP/EPPO. 2014. PP 1/135 (4) Phytotoxicity assessment. pp. 265-273. In: Bulletin OEPP/EPPO Bulletin 3.

Sandral, G.A.; Dear, B.S. 2005. Weed control options in annual pasture legumes. Rural Industries Research and Development Corporation, Barton, ACT. 27 pp. Smetham, M.L. 2003. A review of Subterranean clover (Trifolium subterraneum L): Its ecology, and use as a pasture legume in Australasia. Advances in Agronomy 79: 303-350.

Stewart, A.; Kerr, G.; Lissaman, W.; Rowarth, J. 2006. Pasture and forage plants for New Zealand. Grassland Research and Practice Series 8: 1-128.

Teixeira, C.S.; Lucas, D.; Moot, D.J. 2015. Subterranean clover-literature Review: Project number 408090: Optimization of subterranean clover for dryland pastures in New Zealand. Sustainable Farming Fund 2015-2016.

\title{
Winter rotation length effect on pasture production and animal \\ performance
}

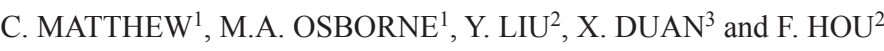
${ }^{1}$ Institute of Agriculture and Environment, Massey University, Private Bag 11222, Palmerston North 4442, New Zealand

${ }^{2}$ State Key Laboratory of Grassland Agro-ecosystems, College of Pastoral Agriculture Science and Technology, Lanzhou University, Lanzhou, 730020, China ${ }^{3}$ College of Animal Science and Technology, Yunnan Agricultural University, Kunming 650201, China c.matthew@massey.ac.nz

\section{Abstract}

Data comparing pasture production in winter pastures subject to 16,48 or 72 -day rotation lengths were recovered from experiments at Massey University to support teaching of grazing management. 'Farmlets' with 16 breeding ewes on 0.8 ha were run from 20112016, and he energy budgeting (MEB). The data illustrate: the roles of pasture cover and animal body weight as buffers to neutralise the impact of weather variability, the use of controlled cover release via the grazing rotation to partially meet winter feed deficit, and the potential value of MEB in systems research. Grass grown from May to September (early pregnancy to mid-lactation) was 3850,4220 and $4840 \mathrm{~kg} \mathrm{DM} / \mathrm{ha}$ for 16,48 and 72 day rotations, respectively. As a result of a reduction in herbage accumulation and the premature release of autumn-saved pasture to animals, the 16-day rotation failed to overwinter the animals in five of the 6 years, the exception being a winter with high pasture growth.

Keywords: winter rotation length, pasture growth rate, teaching pedagogy

\section{Introduction}

The majority of sheep and beef farms in New Zealand manipulate the grazing rotation length to store autumngrown feed as increased cover for release back to stock during periods of lower growth rates in winter. This winter management practice is often referred to as a 'controlled grazing system' (CGS) (Milligan 1981; Sheath et al. 1987). A key component of a CGS is the rationing of herbage intake of stock to levels that provide for body maintenance and pregnancy requirements, while ret.r. requirencents, which is surplus to the reque mass or 'cover'. Longer rotation lengths are achieved by keeping animals longer on a paddock during a grazing event and result in lower residual herbage mass after grazing. Paradoxically, even though herbage removal $(\mathrm{kg} \mathrm{DM} / \mathrm{ha})$ is increased when the rotation is lengthened, individual animals consume less feed/head/ day. This is because intake per animal is progressively reduced during successive days of a paddock grazing event as herbage height is lowered. Daily herbage intake of animals in a rotational grazing event can be monitored by calculating the herbage removed during grazing and dividing by the grazing intensity (animal. days/ha) (Matthews et al. 1999). Herbage consumption at a whole farm level (kg DM/ha/day) is thus determine by the stocking rate and rotation length.

The optimal rotation length depends on a range of site factors and so can vary greatly between farms. The key factor to plan rotation length is expected winter pasture growth rate; for a higher growth rate, increased stocking rate and decreased rotation length would be indicated and vice versa. Compared to set-stocked (continuously grazed) systems typically practiced in the middle of last century, a CGS allows more animals to be overwintered, enhancing farm carrying capacity and profitability. Little definitive research exists on the question of whether the higher stocking rate possible in a CGS than in a set-stocked wintering system arise simply from the reconciliation of mismatches in time between when the feed grows and when animals need it, or whether the longer grazing rotations in a CGS actually increase pasture growth rates.

To assist teaching of grazing management theory and practice at Massey University, a series of 'farmlets' have been maintained for about 25 years, where final year students working in a group create a small scale CGS on a block of $8 \times 0.1$ ha paddocks with electric fences for subdivision, running from early-May to late-September. Calculations on a per hectare basis are similar to those for a commercial farm. Typically, there are 5 or 8 student groups, each with their own farmlet. For 13 years (2004-2016), 2nd year veterinary students provided with farmlets for the teaching of grazing management theory and metabolic energy based feed budgeting. Farmlet teaching for veterinary students has involved a comparison of outcomes for farmlets commencing with a common herbage mass on 1 May, stocked at 20 ewes/ha, and running 16,48 or 72-day grazing rotation lengths until lambing in midAugust. Near the start of lambing, sheep are set-stocked until late September when they are weighed and the 

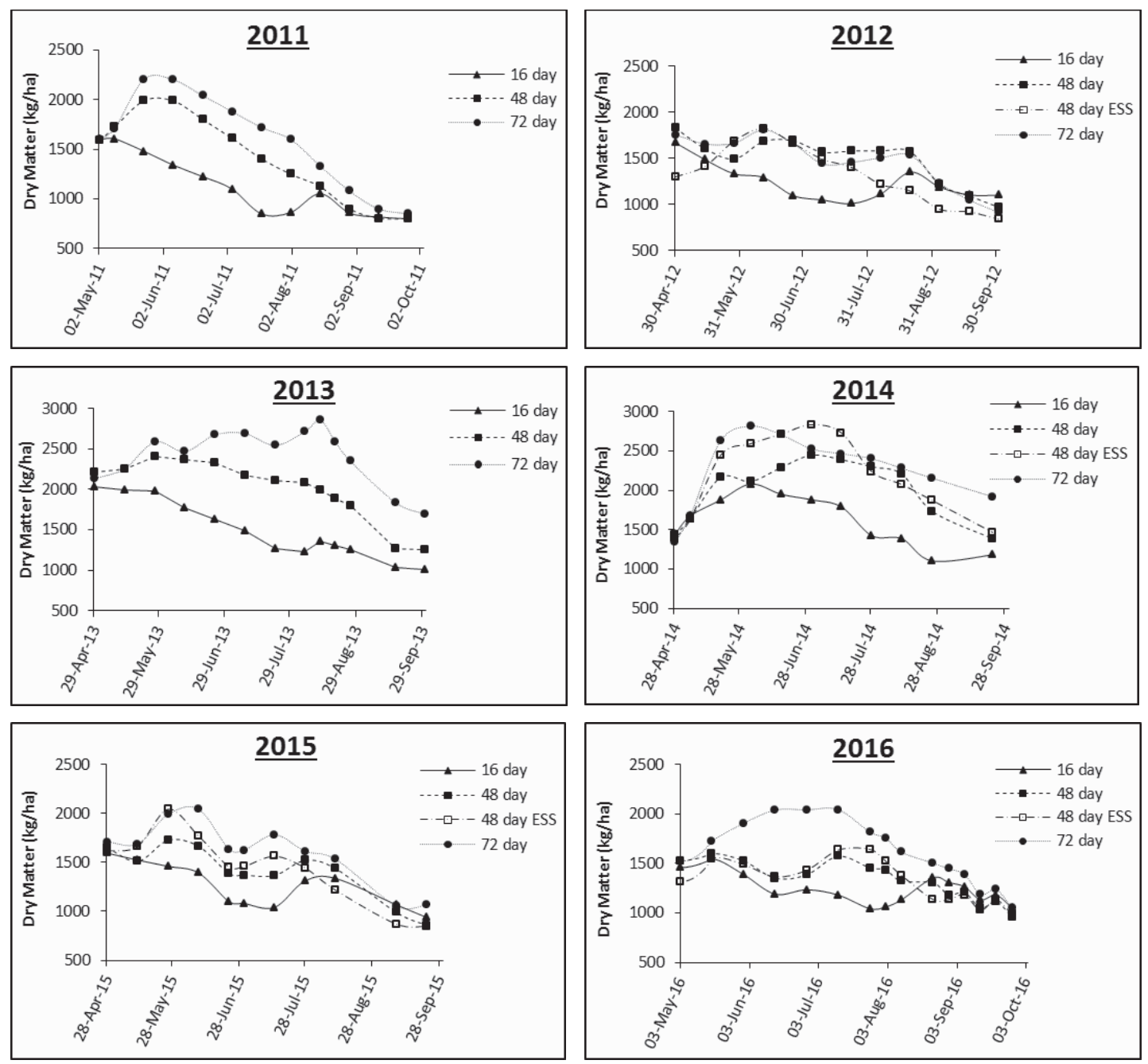

Figure 1 Pasture cover trajectories for farmlets with 16, 48 and 72-day rotations in 6 successive years. Different shapes in different years indicate system resilience to compensate for year to year weather variation.
May or June indicates tactical release of stored feed to animals during winter feed deficit.

experiment terminated. Normally, two identical 48-day rotation farmlets are set up so one can be set-stocked early for lambing.

The primary objective of this paper was to present time series of 6 years data from the veterinary teaching programme farmlets investigating the effect of rotation length on winter pasture growth rate. As animal weights and pasture herbage mass were monitored during the experiments, herbage harvested can be calculated by metabolic energy-based feed budgeting (Nicol \& Brooks 2007). A secondary objective was to record Bnecdotal pedagogical data of failite the possible use of a farmlet methodology for teaching grazing management in other institutions.

\section{Methods}

Farmlet setup

The farmlets were located at the Massey University Pasture and Crop Research Unit (Lat. $40.38^{\circ} \mathrm{S}$, Long. $175.62^{\circ} \mathrm{E}$ ), on a flat to gently undulating terrace with a Tokomaru silt loam (Typic Fragiaqualf) soil type, Olsen $\mathrm{P}=44 \mathrm{mg} / \mathrm{kg}$, and ryegrass-dominant (Lolium perenne) pastures with white clover (Trifolium repens), and a minor presence of some Poa species and herbs such as penny royal (Mentha pulegium). The 8-paldock such pack farmlets were placed on the terrace to make them as similar as possible for factors expected to affect system composition linked to microenvironment factors where topography or soil factors vary. performance, such as differing pasture botanical

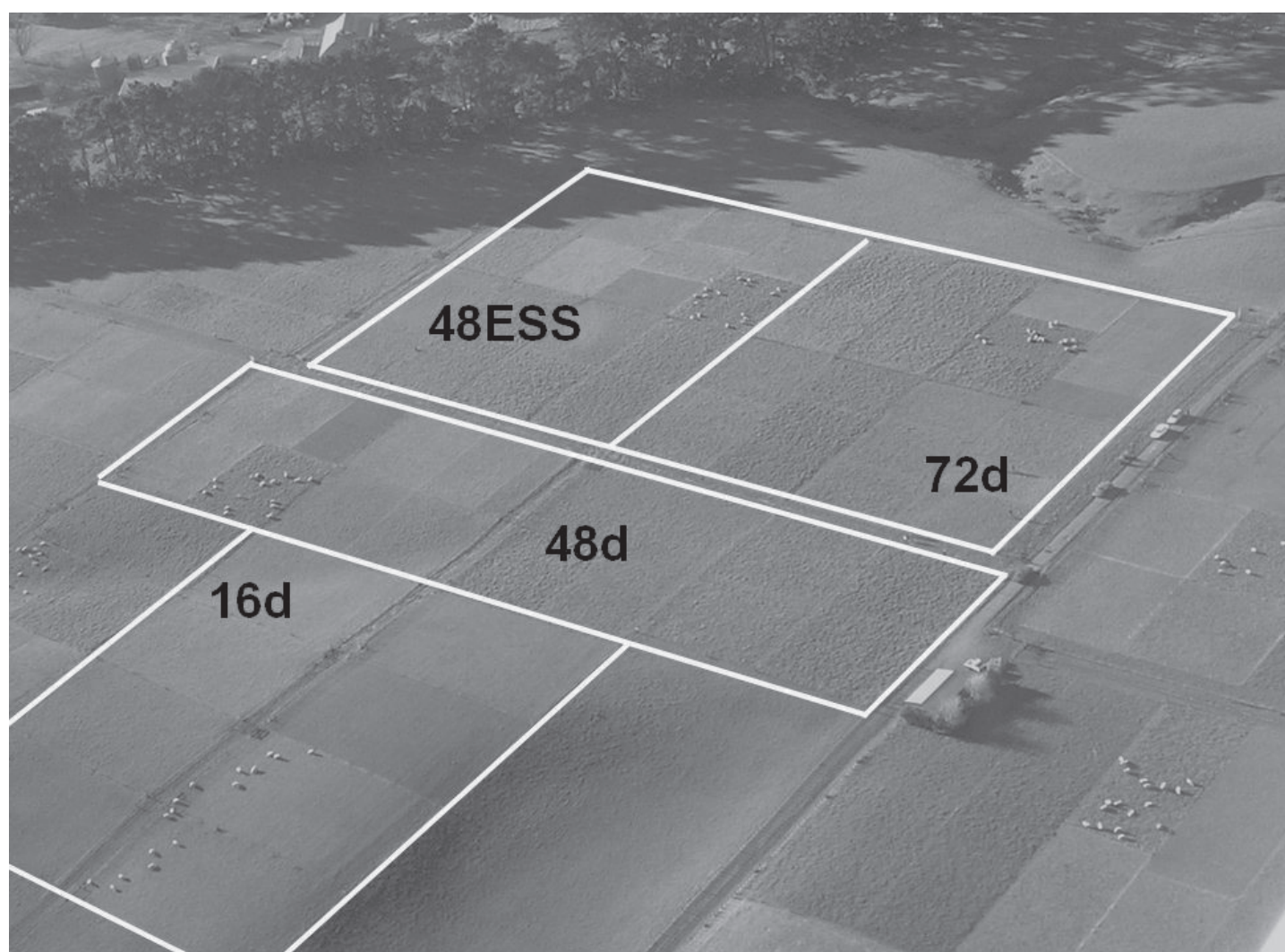

Figure 2 Aerial view of farmlets in early July 2004. The 16-day rotation was achieved with a 2 day grazing duration in each of the 8 paddocks. Sheep were temporarily spread over two paddocks to avoid treading after rain. The 48-day rotation was achieved with a 3 day grazing duration in each half paddock. The 72-day rotation was achieved with a 3 day grazing

A total of 6 farmlets have been used in the experiment from 2011-2016, and the four rotation length treatments were rotated between the 6 farte in a semi-random years of data collection, each rotat in trialled on a 1 last 3 diferent fam enst 3 different far fart 16 Ros stocked in the first week of May each year with 16 Romney-cross breeding ewes (weight range 60-65 kg, but in 2014 and 2015, 57-58 kg, following summer drought) and a common target start cover of about $1600 \mathrm{~kg} \mathrm{DM} / \mathrm{ha}$ (ranging from 1450-2030 kg $\mathrm{DM} / \mathrm{ha}$ ) (Figure 1), depending on summer-autumn pasture growth conditions. Ewes were mated from mid-March to early April, using a tupping crayon to detect early and late submission. Farmlet groups of 16 ewes were balanced for bodyweight and mating date each year. Husbandry details such as anthelmintic dosing, crutching, and vaccination followed normal farm practices. Ultrasound scanning was carried out in June each year and dry ewes replaced with a pregnant one. In all 6 years, the experiment included a 48-day rotation length, considered optimal for this site, and 16 and 72-day rotation lengths considered to be 'deliberate mistakes' that would overfeed and underfeed ewes, respectively, in early winter. During periods of unusually high rainfall, if treading damage to pasture was about to occur, sheep were moved to the next paddock a day sooner than scheduled. By way of context for the rotation length determination, a pasture growth rate of $15-20 \mathrm{~kg} D M /$ ha/day is typical in June and July, at this site. The rotation was transitioned to set-stocking by spreading sheep between paddocks on about 10 August each year, about a week before he start of lambing. In 2012 and 2014-2016 a second farmlet with a 48-day rotation (designated 48ESS) was in to

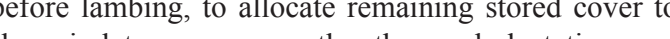
sheep in late pregnancy rather than early lactation, as a third 'deliberate mistake'. Implementation of the four grazing rotation treatments is shown in Figure 2. Lower than normal pasture growth rates in some winters were corrected by application of urea fertiliser $(30 \mathrm{~kg} \mathrm{~N}$ ha in 
2012 on all farmlets; $23 \mathrm{~kg} \mathrm{~N} / \mathrm{ha}$ in 2015 on all farmlets; $37.5 \mathrm{~kg} \mathrm{~N} / \mathrm{ha}$ in 2013 on the 16-day farmlet only; and $45 \mathrm{~kg} \mathrm{~N} / \mathrm{ha}$ in 2016 on 16, 48-day and 48ESS farmlets, but not the 72-day farmlet).

Data collection and metabolic energy budgeting Sheep were typically weighed about seven times during the experiment, using a Prattley sheep weighing crate fitted with either a TruTest model 702 or model XR3000 (itted indicator. There was no September to avoid stress on heavily pregnant ewes o ewes with lambs at foot. Pasture cover was measure fortnightly with a standard rising plate meter by an experienced operator alert to potential issues such as the meter shaft sinking more deeply into wet soils in winter; the equation "x140 + 400" was used to convert meter reading to $\mathrm{kg} \mathrm{DM} / \mathrm{ha}$. Net pasture growth was assumed to equal herbage harvested by animals, which was inferred from the energy requirements of the wheep, determined using metabolic energy budget (MEB) feed calculations (Nicol \& Brooks 2007; Matthew et al. 2010). In all, there were 18 feed budget calculations for the three rotation length treatments over 6 years and a further four feed budget calculations for the additiona farmlet treatment that was set-stocked early in four of the 6 years (spreadsheet available from the authors on request).

Herbage metabolisable energy (ME) was assumed to increase gradually from $11.8 \mathrm{MJ} / \mathrm{kg}$ DM in May to $12.5 \mathrm{MJ} / \mathrm{kg} \mathrm{DM}$ in September (based on occasional near infrared spectroscopy testing and personal communication from M.G. Lambert); pastur consumption by animals was inferred as (energy requirement of sheep) divided by herbage ME. Body maintenance requirements were assumed to be 0.6 $\mathrm{MJ} / \mathrm{kg}^{0.75}, K_{\mathrm{g}}$ as 45 and $30 \mathrm{MJ} / \mathrm{kg}$ liveweight gain fo ewes and lambs, respectively, and energy recovery ewes and la . For the cases where farmlets differed in $\mathrm{N}$ fertiliser applicatio rate, a response to $\mathrm{N}$ of $10 \mathrm{~kg} \mathrm{DM} / \mathrm{kg} \mathrm{N}$ was assumed, resulting in $375 \mathrm{~kg}$ DM/ha being deducted from modelled grass growth on the 2013 16-day farmle and $450 \mathrm{~kg} \mathrm{DM} / \mathrm{ha}$ added to modelled grass growth on the 2016 72-day farmlet. The $\mathrm{N}$ fertiliser response was assumed to convert to lamb bodyweight at 1.375 $\mathrm{kg}$ lamb bodyweight/ha/kg N/ha a conversion deduced by a metabolic energy calculation assuming $33 \%$ of feed energy in the system allocated to lamb growth, and production data were adjusted accordingly for those two cases.

Summary data for the 22 data points from the four grazing management regimes tested over the 6 years of data collection were subjected to ANOVA using the GLM command of Minitab version 10.51, with factors of Farmlet block (A-F), year (2011-2016) and, grazing rotation treatment (16-day, 48-day, 48ESS, 72-day). When Farmlet block was found to be non-significant for all but one summary statistic analysed, this term was removed from the model and a two factor GLM, testing for effect of year and grazing rotation treatment used to assess the data. Given that years served as replicates for grazing rotation treatments, a year $\mathrm{x}$ grazing treatment interaction was not included in the model and was in fact the error term for the model.

\section{Results and Discussion}

\section{Tarm system implications of rotation length}

A key point of interest in any discussion about grazing management is whether the available options change the outcome by (i) compensating for variability in pasture growth rate, (ii) changing the timing of consumption of feed by stock, (iii) changing the quantity of feed consumed by stock, or (iv) the quality of feed consumed. With respect to compensating for vaibility, paster growth rate is subject to random year to year weater varion outside of a farmers cour. In this sudy May - September anor's control. In this study across secter . ha in 2011 to $5060 \mathrm{~kg} \mathrm{DM} / \mathrm{ha}$ in 2014, with "lowgrowth' episodes of 1-3 weeks occurring in any of the 5 months from May to September. Ironically, the high winter growth in 2014 followed a severe summer drought, leading to low animal liveweight and pasture cover (Figure 1) at the start of the farmlet experiment in that year. Farm systems must be resilient to absorb weather variation; the variability of feed reserve accumulation and allocation between years in Figure 1 represents resiliency of the system to absorb the year to year weather variation. For example, use of stored cover commenced in June in 2011, but occurred mainly in August in 2013. Another resiliency factor in the system is ewe body weight. Across the 22 farmlet eximples assesed, May to Sepenber chang in ewe ext MEB calculations equated to $1430 \mathrm{~kg}$ DM/ha buffering of feed supply variability. Accordingly, across the 22 farmlet examples, ewe liveweight loss over winter was strongly correlated with total herbage accumulation $\left(\mathrm{R}^{2}=0.682 ; \mathrm{P}<0.001\right)$

With respect to timing of feed release, the fall in cover between start and end points represents a feed reserve available to partially cover winter feed deficits in periods of low pasture growth. This results in more 'herbage consumed' in winter than was grown (Table 1 ), and the timing of release of this feed reserve was under the farmer's control through manipulation of rotation length. Figure 1 shows the accumulation of reserve feed in May at this site, except for 2012, and the timing of release of the reserve feed over the following winter and early spring. Compared to the 48-day rotation, the 72-day rotation consistently built a greater reserve (through restricting herbage intakes of animals) (Figure 1), and moves distribution of the reserve feed until later in winter, whereas the 16-day rotation consistently allocated the reserve to animals in June and July (through allowing higher intakes to occur at that time). The question of timing of feed release has to be placed in context with animal status, the ewes being in late-pregnancy in late-July and lactating from lateAugust August with requirements of approximately 1.8 and 2.5 $\mathrm{kg}$ DM/hear/day, respectively. Hence, later release of the feed was a better fit to animal requirements. In this series of experiments early winter reserve allocation to animals via a 16-day rotation resulted in a need to supply additional feed (grazing off-farm or $\mathrm{N}$ fertiliser) in every year except the high growth winter of 2014 when stocking rate was also reduced to 17.5 ewes/ha to facilitate recovery from summer drought Meanwhile the 'deliberate mistake' of early set-stocking saw a nonsignificant trend of reduced herbage accumulation after set-stocking (2070 kg DM/ha versus $1940 \mathrm{~kg} \mathrm{DM} / \mathrm{ha}$, Table 1) that may have been biologically real, and a significant $(\mathrm{P}=0.051)$ reduction in lamb weight/ha compared to 48 and 72-day rotations (Table 1), which can be attributed to partial shift in allocation of reserve feed from early lactation when ewe energy requirement

Table 1 Grazing rotation length effect on herbage grown ( $\mathrm{kg} \mathrm{DM} / \mathrm{ha}$ ), lamb numbers and weights, and ewe body weight change from May to September in farmlet systems imitating commercial lamb production. Difference between May to September total growth and herbage consumption reflects average cover decline $(\mathrm{kg} \mathrm{DM} / \mathrm{ha})$ during the experiment. Growth periods: $1^{\text {st }} 5$ weeks - period of herbage storage; June/July - period of low herbage mass on the 16-day rotation; late-July onwards represents the set-stocked period; difference
starting and closing farmlet herbage mass.

\begin{tabular}{|c|c|c|c|c|c|c|c|}
\hline & \multicolumn{4}{|c|}{ Grazing Rotation } & \multicolumn{2}{|c|}{$\mathbf{P}$} & \multirow{2}{*}{$\frac{\text { SEM }}{\text { Rot." }}$} \\
\hline & 16-day & 48-day & 48ESS & 72-day & Rot. & Yr. & \\
\hline \multicolumn{8}{|l|}{ Herbage DM (kg/ha) } \\
\hline Growth $1^{\text {st }} 5$ weeks (May) & 1040 & 1200 & 1468 & 1550 & 0.010 & 0.001 & 100 \\
\hline Growth Jun/Jul (7 weeks) & 710 & 940 & 990 & 860 & 0.186 & 0.018 & 84 \\
\hline Growth from late July & 2090 & 2070 & 1940 & 2420 & 0.090 & NS & 122 \\
\hline Growth: total May-September & 3850 & 4220 & 4470 & 4840 & $<0.001$ & 0.001 & 110 \\
\hline Herbage consumption & 4640 & 5090 & 5060 & 5563 & 0.005 & NS & 143 \\
\hline \multicolumn{8}{|l|}{ Animal performance } \\
\hline Lamb no. (mean 6 years) & 19.0 & 20.8 & 19.3 & 21.0 & 0.120 & 0.002 & 0.67 \\
\hline Lamb weight (kg/head) & $15.1^{\#}$ & 14.7 & 14.1 & 15.1 & NS & $<0.001$ & 0.29 \\
\hline Lamb weight $(\mathrm{kg} / \mathrm{ha})^{+}$ & 345 & 384 & 329 & 390 & 0.051 & 0.018 & 13.7 \\
\hline Ewe weight change $(\mathrm{kg})$ & 1.8 & -2.5 & 0.3 & 3.4 & 0.077 & $<0.001$ & 1.50 \\
\hline
\end{tabular}

Abbreviations: P, probability; SEM, standard error of mean; 16 day, 48-day, 72-day denote rotation lengths; 48 ESS, 48 day rotation set-stocked early; NS "Multiply SEM by 1.3 for grazing rotation 48 ESS because only four of 6 years data were available.

is higher to late pregnancy when requirement is lower. grown, assessment by MEB methodology revealed tifing of reserve discussed above, there were also differences between he rotation lengths in herbage accumulation with the -day rotation averaging $26 \%$ more feed grown than 16-day feed rotation, and $11 \%$ more feed grown than the average of the two 48-day rotations $(\mathrm{P}<0.001$, 作 and 16-day rotations the drop in lamb production with reduced feed grown in the 16-day rotation was not day rotation required grazing off-farm or additional $\mathrm{N}$ fertiliser in five of the 6 years (not included in 'Herbage consumed' in Table 1), so lamb production costs were igher under the 16-day system. (o loss of herbage

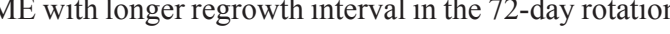
for the 72-day rotation was greater than for the 48-day 
lamb production/ha of the latter equalled that of the former, the herbage accumulation advantage of the 72-day rotation was underestimated in proportion to any loss of herbage quality, and the overall impact on animal performance of this rotation looks more positive than negative (Table 1).

\section{Scientific insights}

This pattern of herbage accumulation difference 72>48>16-day, would have been hard to predict from available literature, as alternative logical expectations can be developed from different historical studies. After farmlet setup in May, high residuals after grazing in the 16-day rotation (compared to longer rotation lengths) might have been expected to increase herbage accumulation (Chapman 2016), though in contrast to that there is known to be a period of low accumulation following defoliation (Matthew et al. 1991) and in set-stocked swards at lower herbage mass (Birchan \& Hodgson 1983), and there is an old New Zealan farm extension adage "grass grows grass". Hence the present results support those studies that indicate loss of growth potential in ryegrass after defoliation, so that the more frequent the defoliation, the greater the herbag production loss, even at residual herbage mass after grazing as high as $1500 \mathrm{~kg} \mathrm{DM} / \mathrm{ha}$. At the high herbage mass end of the spectrum, it is perhaps surprising that there was no evidence of loss of growth to senescence in he 72 day robion other than a non-signifcant tient in June/Jly gowh (860 vesus $990 \mathrm{~kg}$ DM/he, Tale 1). The leaf apea (86 interval in Palme coldest months of July and August was around 13 days for 1 year of weather data analysed (Matthew et al. 2016), so on this basis the 72-day paddocks should have been at leaf stage six and incurring senescence losses (Fulkerson \& Donaghy 2001). Even so, any increased senescence that did occur was not detectable in the farm system level data, and therefore must have been comparatively small.

From a system perspective, correlations between variables in Table 1 across the 22 farmlets considered in this study, indicated lamb liveweight/ha was most strongly linked to herbage accumulation after setstocking $\left(\mathrm{R}^{2}=0.569 ; \mathrm{P}=0.006\right)$, and increased number of lambs on a farmlet resulted in lower lamb liveweight head $\left(\mathrm{R}^{2}=-0.519 ; \mathrm{P}=0.013\right.$ after extraction of the spring growth effect).

A point for wider consideration from this data analysis is the consistency with which rankings for effect of rotation length on total herbage grown were detected by the MEB methodology across 6 years of experimentation, using just animal liveweight and pasture cover data, and with a coefficient of variation of under 3\% (Table 1). This suggests the potential of MEB analysis in farm systems research is currently underutilised by the New Zealand pastoral industries.
Matthew, C.; Xia, J.X.; Chu, A.C.P.; Mackay, A.D.; Hodgson, J. 1991. Relationship between root production and tiller appearance rates in perennial ryegrass (Lolium perenne L.). pp. 281-290. In: Root growth, an ecological perspective. British Ecological Society special publication No. 10. Ed. Atkinson, D. Blackwell, London

Matthew, C.; Mackay, A.D.; Robin, A.H.K. 2016. Do phytomer turnover models of plant morphology describe perennial ryegrass root data from field swards? Agriculture 6: 28.

Matthews, P.N.P.; Harrington, K.C.; Hampton, J.G. 1999. Management of grazing systems. pp. 153-174. In: New Zealand Pasture and Crop Science. Eds. White, J.; Hodgson, J. Oxford University Press, Auckland.
Milligan, K. 1981. New Zealand Farmer guide to razing management. Supplement to the New Zealand Farmer, December 10, 1981.

Nicol, A.M.; Brookes, I.M. 2007. The metabolisable energy requirements of grazing animals. pp. 151-172. In: Pasture and supplements for grazing animals. Eds. Rattray, P.V.; Brookes, I.M.; Nicol, A.M. Occasiona Publication 14. New Zealand Society of Animal Production, Hamilton.

Sheath, G.W.; Hay, R.J.M.; Giles, K.H. 1987. Managing pasture for grazing animals. pp. 65-74. In: Livestock feeding on pasture. Ed. Nicol, A.M. Occasional Publication 10. New Zealand Society of Animal Production, Hamilton. including the concept of feed storage as cover in periods of surplus for release in later deficit, and the counter-intuitive reality where less herbage is removed in a paddock grazing event in order for the animals to eat more/head/day in a short than in a long rotation. It is not uncommon to receive feedback such as: "because of the farmlet practical I undersood what the farmer was telling me during my summer vacation practical wok:"

\section{ACKNOWLEDGEMENTS}

We thank Simon Orsborn for collection of fortnightly paddock cover data from 2011 to 2014, and Baeley Ravenwood for preparing the charts in Figure 1. We acknowledge the insight of Parry Matthews who pioneered the development of the farmlet teaching methodoly at Massey University about 25 years ago. We thank Professor Kenyon, and Tim Parkinson for their leadership in supporting the farmlet teaching of grazing management. The farmlet design utilised the 1980s research led by Dr Gavin Sheath's team at Whatawhata Hill Country Research Station, featured in a 'Country Calendar' presentation 'Kapai'.

\section{REFERENCES}

Bircham, J.S. Hodgson, J. 1983. The influence of sward condition on rates of herbage growth and senescence in mixed swards under continuous stocking management. Grass and Forage Science 38: 323-331

Chapman, D.F. 2016. Using ecophysiology to improve farm efficiency: application in temperate dairy grazing systems. Agriculture 6: 17.

Fulkerson, WJ.; Donaghy, DJ. 2001. Plant-soluble carbohydrate reserves and senescence - key criteria for developing an effective grazing management system for ryegrass-based pastures: a review. Australian Journal of Experimental Agriculture 41: 261-275.

Matthew, C.; Horne, D.J.; Baker, R.D. 2010. Nitrogen loss: an emerging issue for the ongoing evolution of New Zealand dairy farming systems. Nutrient Cycling in Agroecosystems 88: 289-298. 